\title{
Katalin Tabi
}

\section{Syntactically Honest}

\section{lago's Character as Reflected in János Ács's 1989 Play-text}

\begin{abstract}
As Professor Géza Kállay once remarked, "the price of precision is the need for reduction," so in this paper the field of examination will be scaled down to one part of one Othello performance: lago's character in János Ács's 1989 Kaposvár production. This article is an experiment. It leaves behind nearly all the traditional elements of performance criticism to concentrate solely on the role of the cut text in lago's characterization. In what ways does the transformation of Shakespeare's text change lago's character? What is lago in János Kulka's interpretation like? And, lastly, what does a theatrical play-text add to our understanding of lago? These are the questions to be discussed in this essay with an introduction to a less-known field of Shakespeare research: play-text analysis.
\end{abstract}

Why then, is Cassio honest? (3.3)

This essay is an instance of an undeservedly overlooked field of Shakespeare studies called - tentatively by the author of the present paper - play-text analysis. ${ }^{1}$ I am going to analyse the play-text of János Ács's Othello, performed in Kaposvár in 1989, to find out how the director's cuts shape the characterization of János Kulka's Iago: why certain speeches are kept while others omitted, and certain actions left out while

1. The merit of Charles H. Shattuck in the collection and interpretation of Shakespearean prompt-books cannot be questioned. His most important collections are The John Philip Kemble Promptbooks, 11 vols. (Charlottesville: University Press of Virginia, 1974) and The Shakespeare Promptbooks: A Descriptive Catalogue (Urbana and London: University of Illinois Press, 1965). G. Blakemore Evans also edited a useful collection of Shakespearean prompt-books (Shakespearean Prompt-Books of the Seventeenth Century, published by the Bibliographical Society of the University of Virginia, available online: http://etext.virginia .edu/bsuva/promptbook/index.html). Yet it is conspicuous how small the number of scholarly articles in this field is.

The AnaChronisT 12 (2006): 47-60 ISSN 1219-2589 
others added. Such a scrutiny is necessarily reversed: I saw the production first and analysed the play-text second. Although I will try to rely mostly on the play-text, my results will involve the visual side as well. Certain stage movements will occasionally be described - considering them as stage directions, that is to say parts of the text.

\section{Work, Play-text, Theatre}

Shakespeare's plays have always been trimmed for stage productions either for aesthetic or pragmatic reasons. This is sometimes understood as a curse (by scholars), and sometimes as a challenge (by practitioners). Play-text is the printed version of a production as it was recorded at a particular phase of the rehearsal period. Depending on the proximity of the prompt-book that contains the play-text to the time of the premiere, a play-text can reflect the final version of a production to a lesser or greater extent. Ideally, however, the text is accompanied by a video recording of the performance, which can serve the researcher well. In our case, I derived the text from a recording.

In performance criticism, the significance of the play-text is usually dwarfed by other elements of the mise-en-scène (e.g. lighting, costume, scenery, actor's performance, sound, proxemics, blocking, etc.). In play-text analysis, our main interest is (maybe not surprisingly) the play-text: how the textual transformations affect the meaning and focus of Shakespeare's work in the theatre-making process. There are two justifications for analysing play-texts: The one is the fact that more people go and see a Shakespeare-play in the theatre than read it, so pragmatically speaking it makes more sense to interpret the text that the majority understands as Shakespeare. The other is the argument that a play-text can be regarded as a derivative version of Shakespeare's work (problematic in its material anyway due to the numerous surviving scripts), and as such, it can be interpreted as a text in its own right.

Let me highlight what constitutes the theoretical ground for considering a playtext a legitimate variant of Shakespeare's work. W. B. Worthen proposes the concept of an authorial work which is immaterial and abstract, and which would contain all the elements that the two quartos and the Folio include, exclude or misread. He argues that all the different later versions - no matter whether quartos, editions, or play-texts - derive from this ideal but non-surviving work, and therefore they are all verifiable as legitimate descendants of Shakespeare's work. ${ }^{2}$

2. W. B. Worthen, Shakespeare and the Authority of Performance (Cambridge: Cambridge University Press, 1997), esp. pp. 14-16. 
Philip Edwards asserts in his introduction to The New Cambridge Shakespeare Hamlet (2003) that from the point that Shakespeare entrusted the Chamberlain's men with his play and they started to re-work it for the stage, "degeneration began, and it is at this point that we should arrest and freeze the play, for it is sadly true that the nearer we get to the stage, the further we are getting from Shakespeare." (32) Even if we understand Edwards' concern about Shakespeare's unique poetic style which is necessarily corrupted by pragmatic theatre-makers, we must not forget the good old fact that what Shakespeare was primarily proud of was his sonnets and not his plays, 3 and that he was also an active participant in the theatre-making process. Thus, in the light of Renaissance theatrical tradition, the theatrical approach of Shakespeare's plays seems appropriate. 4

\section{Edition, Translation, Cuts}

The production discussed was played with great critical success in István Eörsi's new translation, but this time, due to the language of the paper, the cut text will be quoted according to the 1988 Oxford edition of the Complete Works. 5 For the sake of convenience, the text of the Oxford edition will be referred to as "Shakespeare's text,"

3. Lukas Erne has proposed recently that Shakespeare prepared his plays with the same devotion for the page as for the stage (cf. Lukas Erne, Shakespeare as a Literary Dramatist [Cambridge: Cambridge University Press, 2003], esp. pp. 131-136), but I believe that his statement does not conclude, only contributes to the page and stage debate.

4. The notion that Shakespearean dramas are primarily written for the stage was rediscovered and highlighted extensively in the second half of the twentieth century (see, for example, the works of J. L. Styan, Stanley Wells, David Bradley, J. R. Brown, or W. B. Worthen). At the same time, the acknowledgement of theatre as an art independent from literature, and not merely a visual translation of drama, evolved due to the achievements of theatre semiotics (see the works of Tadeusz Kowzan, Patrice Pavis, Elinor Fuchs, and Erika Fischer-Lichte). These two tenets seem to point toward the superiority of stage over page even if there will always be scholars who argue for Shakespeare as a literary dramatist - see Lukas Erne's intriguing book mentioned earlier.

5. Stanley Wells and Gary Taylor eds., The Oxford Shakespeare. The Complete Works (Oxford: Clarendon Press, 1988). Naturally, some of the meaning will be lost because of the use of English, but, on the other hand, translation is an interpretative medium that would divert our attention from the focus of this article, the results of cutting, to the domains of poetic textual interpretation. Since this paper is aiming to give rather a formal (syntactic) analysis, the English text can even be called an advantage (but I will, of course, indicate when a phrase or sentence gains special or additional meaning due to the Hungarian translation). 
and the play-text as "Ács's text." Sometimes Iago will be called "Kulka's Iago" to distinguish him from "Shakespeare's Iago." When both Shakespeare's and Ács's texts are quoted for comparison, Ács's will always come first and Shakespeare's second.

Cuts can have several functions above which the leading principle is to define the length of the performance. Nevertheless, even cuts intended primarily to shorten the playing time can have interpretive power. Abridgement due to the repetition of information is called "accordion cut" in theatrical jargon. This does not normally affect the meaning, but often does the rhythm of a scene. Other cuts may determine the rhythm of the whole performance (e.g. scene omissions), establish cast dynamics (the weight and importance of characters), help characterization (e.g. by highlighting some dominant characteristics), narrow down or concentrate the plot for the sake of theatrical effect - or all these simultaneously. ${ }^{6}$ Additions and transpositions also belong to the editorial apparatus of a director, but in this analysis the cuts sharpening Iago's character are going to be in the focus of attention.

\section{Words, Questions, Silences}

Shakespeare's Othello starts with a dialogue between Iago and Roderigo. In Ács's production this is preceded by a "semi-dumb" show. When the curtain goes up, we can see Othello wrestling Iago to the ground surrounded by soldiers. After his victory Othello washes and drinks. He offers a cup to Cassio first, and Iago second. Cassio refuses it politely, Iago accepts it. Everybody leaves except for Iago still standing with the cup in his hand. Some soldiers call from within: "Cassio! Cassio! Cassio!" - he is already a very important man. Iago breaks the cup furiously, his hand starts bleeding, and he says "Damn it!" At this point Roderigo enters. Iago's despair is obvious from the start. His failure in the wrestling and the echoing of Cassio's name make him swear and break the cup. He is wounded at the very beginning both physically and emotionally.

If we look at the first conversation between Iago and Roderigo in Shakespeare's text, it is surprising how much more Iago speaks compared to Roderigo. This discrepancy creates a theatrical effect bordering on the comic. Iago's too much talk about his own smallish interests make him, similarly to Brabantio, a comic figure lacking dramatic density. This comic tone, however, is missing from Kulka's Iago

6. It should also be mentioned, however, that in many cases cuts do not tell us anything about the director's intentions - or there are no cuts at all, but on stage we get an ingenious interpretation. 
because of the injury he suffered in the opening scene. Therefore he rather appears as a tragic figure, and, accordingly, Ács cuts his speeches considerably partly to make the opening scene speedier, and partly to emphasize his dramatic superiority over the dunce Roderigo. With fewer words Kulka's Iago can say more. In Ács's text there are many short replies that create tension. Only Iago's detailed speeches of how he has lost the chance of promotion, and of his jealousy and detestation of Michael Cassio are longer, but the other replies contain no more information than necessary. His second, longer speech when he reveals his real deceitful nature to Roderigo is heavily cut:7

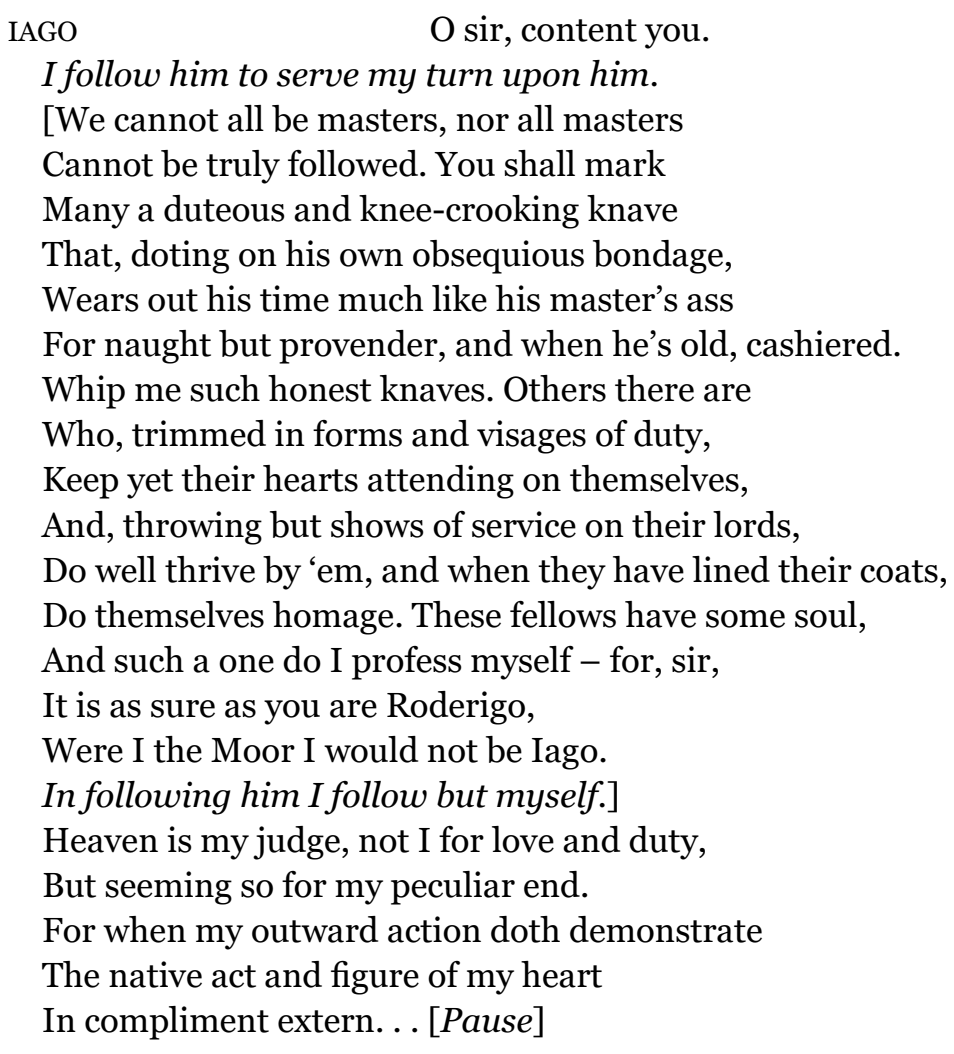

7. In this paper, italics are used when new text (i.e. the director's invention) is inserted. Stage directions in square brackets normally indicate Ács's directions. In this quotation, however, the square brackets enclose the text which has been cut, and I have highlighted the lines with similar meaning in bold to indicate the repetition. 
I am not what I am. [Pause]

Roderigo! Call up her father,

Here he lives.

This speech in the very first scene tells a lot about Kulka's Iago: fragmental thoughts construe his style and make his presence unfathomable. The account of the different types of knaves is omitted, and Ács takes up the line of speech where Shakespeare's text repeats itself. First, Iago establishes that his outward action will differ from his inner intention, and then in a five-line metaphor Shakespeare's Iago continues to muse upon what would happen if he exposed his inner thoughts. He would get defenceless: "I will wear my heart upon my sleeve / For daws to peck at." Kulka's Iago starts this metaphor, but does not finish it. As if the thought itself that he could be revealed made him shiver and more resolute than ever. He pauses in the middle of the sentence, and his thoughts take a turn: "I am not what I am." This famous, yet enigmatic, sentence summarizes the essence of his identity. Introducing it by a halfstifled sentence and placing it between two pauses mark its importance.

Just as unexpectedly as his idea of pretence took shape does Iago realize that he could spoil and ruin Othello's happiness if he betrayed him to Desdemona's father. In Shakespeare's text the idea of calling up the father is preceded by Roderigo's speech. In Ács's text, his lines are omitted, and Iago switches to this new thought without interruption immediately after his self-definition. This way his speech perfectly shows the nature of his cunning mind: he is constantly speculating, calculating and plotting in a nick of time. Kulka's Iago's text reveals expressively how his thoughts are born on the spot.

The same rhetoric can be observed in 1.2 in Othello and Iago's first meeting. Kulka's Iago is seemingly talking about Brabantio's rage against Othello, but in reality he is much more interested in Othello's wedding:

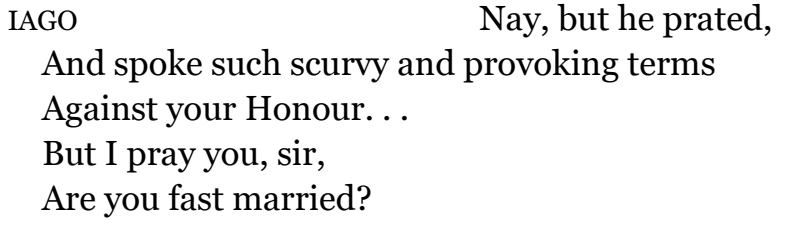

Again, he abruptly cuts off the thread of one thought to start another. He leaves the sentence unfinished because he uses speaking only to conceal his ceaselessly working mind, or to summon up courage to take the next step. This Iago is constantly scared and daring at the same time. His half sentences suggest that he is always thinking about something else than what he is talking about - he is meaning 
one thing, and saying another. He is constantly speculating and maintaining control. The crucial point for him is that he must not be silent otherwise he might lose control over the situation. (This is what actually happens when in the last act he goes silent, refuses to speak, and this brings about his fall.)

It is commonly known that speaking helps thinking. This is also true when we are alone, although we rarely utter full sentences or elaborated thoughts, but rather fragments. Since James Joyce and Virginia Woolf, this inner ceaselessly buzzing voice has been known as the stream of consciousness. Kulka's Iago's half sentences beautifully display this natural working of the mind: the stream of consciousness that gushes out of him in each and every soliloquy. Shakespeare's Iago puts different thoughts and ideas next to each other seemingly without any logic. This uncontrollable speech-stream is stifled in Ács's text, for instance in Kulka's Iago's first soliloquy at the end of 1.3:

Thus do I ever make my fool my purse -

For I mine own gained knowledge should profane

If I would time expend with such a snipe But for my sport and profit. I hate the Moor, And it is thought abroad that 'twixt my sheets He has done my office. I know not if't be true, But for mere suspicion in that kind. . .

\section{He holds me well:}

The better shall my purpose work on him. Cassio's a proper man. How to get. . .

I ha't!
Thus do I ever make my fool my purse For I mine own gained knowledge should profane

If I would time expend with such a snipe But for my sport and profit. I hate the Moor, And it is thought abroad that 'twixt my sheets He has done my office. I know not if't be true, But I, for mere suspicion in that kind, Will do as if for surety. He holds me well: The better shall my purpose work on him. Cassio's a proper man. Let me see now, To get his place, and to plume up my will In double knavery - how, how? Let's see. After some time to abuse Othello's ears That he is too familiar with his wife; He hath a person and smooth dispose To be suspected, framed to make women false.

The Moor is of a free and open nature, That thinks men honest that but seem to be so, And will as tenderly be led by th' nose As asses are. 
I ha't. It is ingendered. Hell and night Must bring this monstrous birth to the world's light.

Although natural on the one hand, it is scary on the other how Kulka's Iago explains nothing fully. There are two points where he leaves Shakespeare's text: once when he makes surety out of "mere suspicion" ("But for mere suspicion in that kind. .."), and three lines later when he states "Cassio's a proper man." After this, his machinations, the birth of the plot - displayed in Shakespeare's text in detail - are just indicated in two fragments: "How to get. . . / I ha't!" and, as Hamlet would say, "the rest is silence."

What the director did to Shakespeare's text was that he made it theatrically more effective. Firstly, the lack of information creates suspense and winds up the audience; and, secondly, Iago's plot will become clear enough anyway in the following scenes of the performance, so giving all the details here could even be called unnecessary if we did not feel sorry for the brilliant lines: "Hell and night / must bring this monstrous birth to the world's light."

It is also characteristic of Kulka's Iago that he utters certain words in solo. These words snuggle into Iago's head in Ács's text. At the end of 1.3 he is trying to dissuade Roderigo from drowning himself. Iago believes that Desdemona cannot love the moor. At a certain point he says:

Therefore put money in thy purse. If thou wilt needs damn thyself, do it a more delicate way than drowning. An erring barbarian... a super-subtle Venetian woman... a frail vow. . . A pox o' drowning thyself.
Therefore put money in thy purse. If thou wilt needs damn thyself, do it a more delicate way than drowning. Make all the money thou canst. If sanctimony and a frail vow betwixt an erring barbarian and a super-subtle Venetian be not too hard for my wits and all the tribe of hell, thou shalt enjoy her; therefore make money. A pox o' drowning thyself - it is clean out of the way.

Kulka's Iago withholds the details. He ruminates the words, tastes them until the idea is ripe and suddenly pops out. We cannot help wondering what is going on in his mind again. 
The way a word gets stuck in Kulka's Iago's mind can be seen in 2.3. Talking of Desdemona's chastity Roderigo uses the phrase "blessed condition," which is followed by Iago's speech:

Blessed! Blessed! If she had been blessed, she would never have loved the Moor. Blessed pudding! Didst thou not see her paddle with the palm of his hand? Didst not mark that?

He is playing with the word "blessed," he is tasting it, chewing it, and stores it up in his mind. Then, when Roderigo has left, he carries on with his second soliloquy:

That Cassio loves her?

Desdemona!

The Moor!

$\mathrm{He}$ is of a constant, loving, noble nature,

And I dare think he'll prove to Desdemona

A most dear husband. Now I do love her too,

Not out of absolute lust - though peradventure

I stand accountant for as great a sin -

But partly

For that I do suspect the lusty Moor

Hath leapt into my seat.

And nothing can or shall content my soul

Till I am evened with him, wife for wife -

'Tis not enough. Jealousy. Jealousy. . . Blessed. . . Blessed!

[Noise from within]

Instead of whole sentences he uses words again: "Desdemona! / The Moor!" and then, just like in his first soliloquy, he drops the half of Shakespeare's text - which is the repetition of his villainous plans anyway - and finishes his speech with Ács's invented words.

From a theatrical point of view, it has to be admitted that Iago's plot is overdiscussed in Shakespeare's text. He displays his plans in his first (1.3), second (2.1) and third soliloquies (2.3), which is more than sufficient (although no doubt all the three speeches are rhetorically excellent). Modern audiences want action, not oration, and prefer solving the puzzle themselves to receiving it ready-made.

In Ács's performance Iago suppresses his intentions in his first soliloquy, then later when Desdemona arrives in Cyprus in 2.1, all we can suspect is that his plans involve Cassio and Desdemona, and it is only his second soliloquy when he utters the 
word "jealousy" at last. First this word refers to his own injury (Othello's alleged affair with his wife), but then the direction of reference turns immediately towards Othello, and the second utterance of the word indicates already that the plot is born. The same thing happens to the word "blessed." Now, coupling it with the word "jealousy," the whole conception is mapped out in front of him.

Iago likes asking questions. This is another mischievous device of his verbal repertoire. By asking questions he avoids the charge of lie or libel: he states nothing, he is responsible for nothing. In Shakespeare's text, the paragon of this device is $4.1 \mathrm{in}$ which Iago entices Othello into the strong suspicion that Desdemona cheated on him with Cassio. Ács, to enhance this element in Iago's character, adds a few more to the Shakespearean questions. In 1.2, when Othello and Iago first meet, Iago starts the conversation in medias res telling Othello the inner conflict between the force to fight and his innate meekness. To wring an approval out of Othello, Kulka's Iago does not state but asks, "Do I lack iniquity, / Sometime, to do me service?" - to which Othello replies " 'Tis better as it is." That is to say, it is better that Iago is gentle and submissive.

Later on, in the temptation-scene (3.3), Iago uses questions to make Othello lose his faith in Cassio's honesty:

OTHELLO Is he not honest?

IAGO Honest?

OTHELlO Honest? Ay, honest. ...

IAGO I dare be sworn I think that he

is honest.

OTHELLO I think so too.

IAGO Men should be what they seem,

Or none.

OTHELLO Certain, men should be what they seem.

IAGO Why then, is Cassio honest?
OTHELLO Is he not honest?

IAGO Honest, my lord?

OTHELLO Honest? Ay, honest. ...

IAGO I dare be sworn I think that he

is honest.

OTHELLO I think so too.

IAGO Men should be what they seem,

Or those that be not, would they might seem none.

OTHELLO Certain, men should be what they seem.

IAGO Why then, I think Cassio's an

honest man.

Kulka's Iago adds one more to the barrage of questions to increase the effect: "Why then, is Cassio honest?" There is a strange game in this scene: both Iago and

8. Cf. "I lack iniquity, / Sometime, to do my service" in Shakespeare's text. 
Othello are trying to avoid the responsibility of uttering the sentence that Cassio is not honest. It is a kind of Ping-Pong match between them, and Ács plays upon this situation when he makes Iago serve the ball back one more time to force Othello to give a final reply.

There is one more occasion, later in this scene, when Kulka's Iago inserts a question talking of Desdemona's deceiving her father:

She that so young could give out such a seeming,

To seel her father's eyes up close as oak,

He thought 'twas witchcraft! Do you remember?

But I am much to blame.

Iago wants to involve Othello in the truth of what he is saying so he asks a yes/no question (a deliberately closed structure!) to which Othello inside involuntarily has to reply "Yes."

There are two more important features of Iago's characterization in Ács's production which express his relation to the other characters. These are his constant disturbance by some noise and his reluctance to join the others. In Shakespeare's text, Iago has a soliloquy at the end of 2.1, and then exits to leave the stage empty for Othello's herald who announces the celebration of Othello's victory and marriage. (This scene, however, is normally left out in performances - in this one, too.) In Ács's text Iago remains on stage completely carried away by the words "jealousy" and "blessed" when noise comes from within that makes him stir and pretend to be there by chance. Montano and Cassio enter to arrange the watch. Iago's third soliloquy at the end of 2.3 is interrupted similarly. He speaks the whole text with only a few cuts, and he is in the middle of his sentence when Roderigo enters unexpectedly:

And by how much she strives to do him good She shall undo...

[Noise from within] Enter Roderigo
And by how much she strives to do him good She shall undo her credit with the Moor.

So will I turn her virtue into pitch, And out of her own goodness make the net That shall enmesh them all.

Enter Roderigo

These intrusions are the moments when we can witness Kulka's Iago's double nature the best. He has to be alert to his environment all the time during the play so that nobody knows about his secret plans. The only time he cannot control his attention is when he is alone indulging in his vicious enterprise. At this time he simply 
switches off, and when someone suddenly enters, we, the audience, cannot help getting excited by the mere thought that he could have been caught. Willy-nilly, we find ourselves in the strange position of worrying about and supporting Iago.

The last thing to be discussed is Kulka's Iago's sly reluctance to join the others. After Othello has been greeted in Cyprus, everybody leaves the stage but Iago and Roderigo. The stage direction says "Exeunt Othello and Desdemona with all but Iago and Roderigo.” Ács is right when he inserts two new lines for Cassio and Iago:

CASSIO Ensign! [He shows Iago that he should follow them] Ensign!

IAGO Coming, coming. . . Coming. [Exit]

It would be natural for Iago to go with them, but he does not want to; he wants to stay behind to continue his business with Roderigo that they started in the opening scene. Although Iago says to an attendant, "Do thou meet me presently at the harbour," which may be interpreted as an excuse for staying behind, Shakespeare's text leaves this scene-change practically unexplained. Ács, by giving a line to Cassio to call to Iago (addressing him by his detested rank!), emphasizes Cassio's superiority and responsibility as well as the tension between Iago and him. Iago repeats his answer several times to disguise his contempt by trying to be funny. In the performance he is even showing the way he is going with his hand as if he said "I'm coming, you dunce, can't you see?” He gets easily frustrated by an innocent call because his mind is already set on dirty thoughts, and any intrusions into these disturb him.

This disturbance can also be observed in 3.2 when Othello sends a soldier to the harbour with some letters and then wants to walk at the works with Iago. In Shakespeare's text Othello sends Iago to the harbour, and walks to the works with some gentlemen. Ács's Othello, by contrast, sends a soldier to the harbour, and wants Iago to go with him. By this, the friendship and trust between Othello and Iago is reinforced:

OTHELLO [from within] Hey, soldier!

SOLDIER Yes, sir.

OTHELLO This letter give to the pilot,

And by him do my duties to the senate. [He throws a kiss to Emilia]

SOLDIER Yes, sir.

OTHELLO Iago, we will be walking on the works. [Exit]

IAGO Yes. [He looks at Emilia]

OTHELLO [from within] Iago.

IAGO Coming! [Exit] 
Iago, before joining Othello, stays on stage to exchange glances with Emilia to let her know that she should conduct Cassio's request appropriately. When Othello calls again, he answers reluctantly. He obviously does not care about the works or Othello, only his own plans. In the previous scene (2.3) Iago explains that he must make his wife "move for Cassio to her mistress." So this eye-contact between him and Emilia before he joins Othello is about their agreement about Cassio's matter. Even if everybody but Othello can see his hesitation to follow the moor, only we, the audience, understand fully that there is more to his hesitant behaviour than mere benevolence.

The same uncertainty can be seen in his farewell to Cassio earlier in 2.3 when the disgraced lieutenant leaves him with the hope that Desdemona will speak for him. After his seemingly kind advice, instead of the conventional farewell of the Shakespeare-text, Kulka's Iago delays his goodnight:

CASSIO Good night.

IAGO [Pause, then he shouts after Cassio.]

Lieutenant!. . . Good night.

CASsIo Good night. Exit
IAGO You are in the right. Good night, Lieutenant. I must to the watch. CASsio Good night, honest Iago. Exit

Cassio is completely crestfallen, so he does not realize that Iago did not answer his goodnight. Therefore when Iago shouts after him with noticeable delay just to say goodnight, he finds it strange. Iago's goodnight is about something else than the innocent Cassio's. His words imply something like "Thank you for taking my advice and helping my plans." He is grateful that Cassio could be convinced so easily, and this takes him one step closer to his aim. However, his goodnight also insinuates something even darker: Cassio's looming death.

\section{Rhetoric, Syntax, Conclusion}

Iago's rhetoric has been thoroughly analysed ever so many times from all sorts of angles. ${ }^{9}$ The present analysis has shown with the method of play-text analysis that the broken sentences, suppressed thoughts, sparkle-like words, well-positioned questions and reluctant replies perfectly shape up and, at the same time, betray Iago

9. One of the latest works in Hungarian is Géza Kállay's excellent book on the language of Othello from a language-philosophical approach: Géza Kállay, Nem puszta szó (Budapest: Liget, 1996). 
in János Kulka's performance. His Iago-interpretation is fundamentally classical. The merit of this stage production lies rather in the fact that Ács's text sharpens up and refines Iago's character not only on the level of semantics, but also on the level of syntax. In Shakespeare's text, Iago does not speak openly about his plans but in the soliloquies. In the group-scenes Shakespeare's Iago always presents a slick and immaculate behaviour. By involving the syntactic element, Ács can achieve that the audience can detect Iago's true nature also in the group-scenes where his attractive way of speaking is betrayed unconsciously by his fragmented sentences. Ács reinforces the theatrical effect by attacking the viewer both semantically and syntactically. The way he cuts the text outlines a forcefully contoured character that rules the performance. Why then, is Iago honest? Although his words and deeds are false and dishonest, the structure of his speeches reflect his fragmented nature - Kulka's Iago is syntactically honest. 